\title{
Vertical distribution of fish and krill beneath water of varying optical properties
}

\author{
Stein Kaartvedt ${ }^{1, *}$, Webjørn Melle ${ }^{2}$, Tor Knutsen ${ }^{2}$, Hein Rune Skjoldal ${ }^{2}$ \\ ${ }^{1}$ Biological Institute, University of Oslo, PO Box 1064, N-0316 Blindern, Oslo, Norway \\ ${ }^{2}$ Institute of Marine Research, PO Box 1870, N-5024 Bergen, Norway
}

\begin{abstract}
The distribution of acoustical scattering layers of fish and krill changed markedly in concert with fluctuating fluorescence (chlorophyll a) in upper waters, possibly due to a varying 'shadow effect'. Beneath clear waters on the outer Norwegian shelf (about $300 \mathrm{~m}$ depth), mesopelagic fish (Maurolicus muelleri) were located at approximately 150 to $200 \mathrm{~m}$ by day. Krill (mainly Thysanoessa inermis) was primarily found below the mesopelagic fish and above planktivorous demersal fish (Norway pout Trisopterus esmarkii). The vertical distributions changed abruptly across a front into water with less light penetration associated with increased fluorescence (chlorophyll a). Mesopelagic fish ascended by about $100 \mathrm{~m}$ accompanied by a rise of krill. Demersal fish left the benthic boundary zone, with ascending Norway pout foraging in the lower part of the krill layer. We suggest that the intermediate light conditions inside the front provided an 'antipredation window' (sensu Clark \& Levy 1988: Am Nat 131:271-290) and thereby favorable feeding conditions for the planktivore. These results indicate that properties of upper layers may impact plankton and fish distributions and their predator-prey interactions throughout the water column on continental shelves.
\end{abstract}

KEY WORDS: Shading · Visual predation - Plankton behavior

\section{INTRODUCTION}

Fish generally depend on vision for efficient foraging (e.g. Zaret \& Suffern 1976, Gliwicz 1986, Thetmeyer \& Kils 1995). The light level and optical properties of the environment, therefore, are key elements for predatorprey relationships of fish and plankton with piscivores and planktivores (Clark \& Levy 1988, Aksnes \& Giske 1993, Giske et al. 1994, Rosland \& Giske 1994, Fiksen \& Giske 1995)

The vertical distribution of plankton and fish may reflect a trade-off between food intake and mortality risks (Johnsen \& Jakobsen 1987, Clark \& Levy 1988, Rosland \& Giske 1994). Plankton often seem to optimize this trade-off by inhabiting upper, food rich layers in the shelter of darkness by night, and hiding at depth by day. Piscivores may constrain foraging behavior of planktivores so that the ratio of planktivore feeding rate to mortality risks reaches a maximum at intermediate levels of light intensity (Clark \& Levy 1988).

•E-mail: steinka@bio.uio.no
Over continental shelves sufficient light may reach the bottom for visual predators to detect their prey throughout the water column. Predation on plankton by demersal fish is prominent on shallow banks (Isaacs \& Schwartzlose 1965, Hobson \& Chess 1986, Genin et al. 1988, 1994, Hobson 1989). Here, fish forage on vertically migrating individuals that, after having been carried by surface currents onto the shelf-bank at night, are trapped by the relatively shallow bottom during their morning descent. Apparently, plankton from oceanic populations are especially vulnerable to predators in this setting, which is very different from their normal daytime habitat (Hobson 1989).

Banks and continental shelves are also inhabited by more or less resident plankton populations (e.g. Hobson \& Chess 1986, Barange \& Pillar 1992, Kaartvedt 1993). Shelf species are adapted to their relatively shallow habitat, and probably possess behavioral traits to counteract the threat of both pelagic fish from above and bottom associated fish from below. Recent studies of freshwater and marine zooplankton have shown that occurrence of pelagic fish may stim- 
ulate downward plankton swimming by day (Bollens \& Frost 1989, 1991, Bollens et al. 1992a, b. Dawidowicz \& Loose 1992, Frost \& Bollens 1992, Neill 1992, Huang et al. 1993). Studies on plankton behavioral responses to the presence of demersal predators appear to be lacking.

In this paper, we address the distribution of mesopelagic planktivorous fish (Maurolicus muelleri), krill (Thysanoessa inermis), and bottom associated planktivorous fish (Norway pout Trisopterus esmarkii) along a cross-shelf transect from oceanic waters and through a front on the shelf. We suggest that shading of light transmission by phytoplankton may be essential in governing the distribution of fish and krill and their predator-prey relationships, and we report on possible krill behavior that may reduce interactions with their demersal fish predators.

\section{MATERIAL AND METHODS}

The study was carried out off northern Norway in April 1993 (Fig, 1). A cross-shelf transect was first covered by RV 'Johan Hjort' and, about 5 h later, by RV 'G.O. Sars' The distributions of macroplankton and fish were continuously recorded acoustically by shipmounted SIMRAD EK 500, $38 \mathrm{kHz}$ and $120 \mathrm{kHz}$ split-

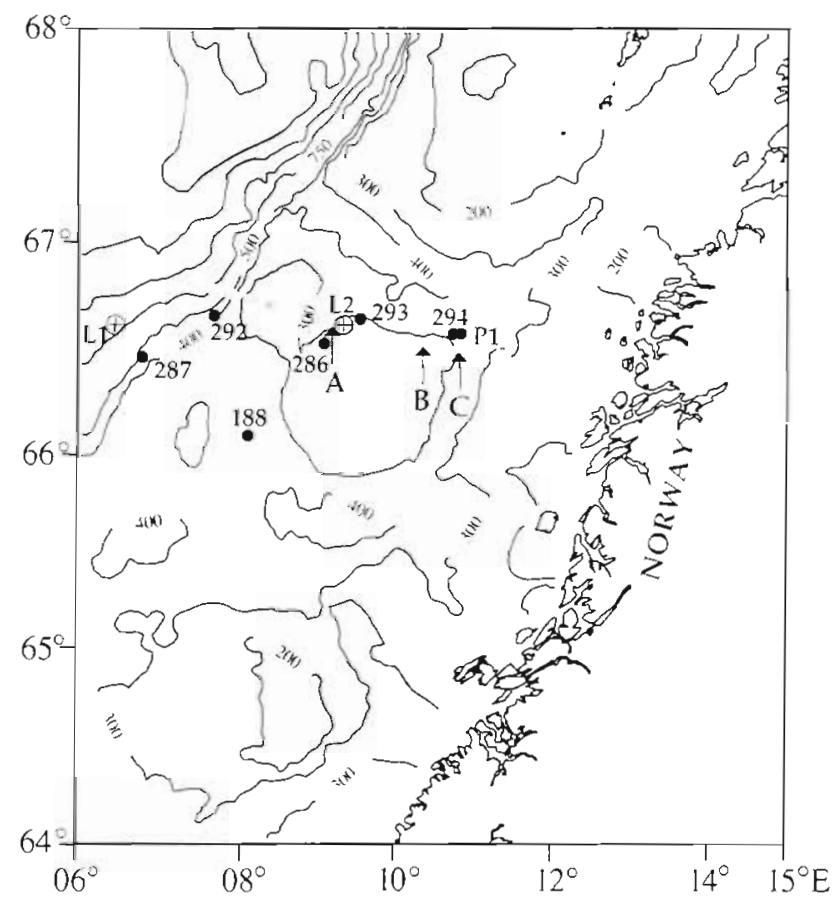

Fig. 1 Map of study area with bottom contours. Track of acoustical transect is indicated by dotted line. Points A, B, and $C$ depict locations studied and referred to in other figures. Locations of trawling stations (see Table 1), and stations for light measurements (Stns L1 and L2) are given beam echo sounders. Concurrent continuous measurements of salinity, temperature and fluorescence were made in water from the ship's sea water pump (taken at $5 \mathrm{~m}$ ), using a Meerestechnik 1500 mini-CTD (conductivity, temperature, depth profiler) and a Turner design fluorometer. Water samples for chlorophyll a (chl a) analyses were taken at $10 \mathrm{~m}$ with Niskin bottles, and $260 \mathrm{ml}$ subsamples were filtered through Whatman GF/C filters and analyzed by standard methods. A linear relationship was found between these chl a values at selected stations and corresponding data from the continuous measurements of fluorescence along the transect $(\mathrm{Chl} a=11.5$ Fluorescence -5.3 ; $r^{2}=0.88, n=9$ ). This relationship was used to convert the continuous fluorescence measurements into chl a values.

Vertical profiles of salinity, temperature, fluorescence and light extinction were measured at selected stations. We used Neil Brown CTDs (apparently giving salinity values about $0.1 \%$ higher than the mini-CTD), and a Seatech fluorometer that was attached to the CTD of RV 'G.O. Sars'. Downwelling irradiance was measured with a Biospherical light meter, which measured light on separate wavelengths and was also equipped with a CTD and a fluorometer.

For identification of acoustical targets, soundscattering layers (SSLs) were sampled by various midwater trawls [Harstad trawl (Nedreaas \& Smedstad 1987); Method Isaacs-Kidd midwater trawl (MIK; Munk 1988) and Åkra trawl (Valdemarsen \& Misund 1995)]. Sampling depths were monitored by a Scanmar trawl eye or Scanmar depth sensor. Details are given in Table 1.

Feeding of Norway pout was investigated from analysis of stomach content of fish caught in the Harstad trawl. Stomachs were dissected out, injected with $10 \%$ formalin and stored in separate jars with $10 \%$ formalin.

\section{RESULTS}

\section{Acoustical recordings}

Off the shelf, and on the outer part of the shelf, recordings at $38 \mathrm{kHz}$ revealed a narrow SSL situated at about 150 to $200 \mathrm{~m}$ by day (e.g. to the left in Fig. 2). A more diffuse layer of weaker targets was observed below, extending almost down to the bottom on the outer shelf, where they sometimes occurred in relatively dense aggregations (i.e. denser than appears to the left in Fig. 2). Fairly strong targets (fish) dominated in the benthic boundary zone.

The mesopelagic fish Müller's pearlside Maurolicus muelleri prevailed in catches from trawling aimed at 
Table 1. Trawl catches in acoustical structures designated by their relative vertical distribution during daytime. Locations of stations are depicted in Fig. 1. Time refers to start of tow and is given as European standard time (GMT +1 h). \&T: Akra trawl; HT: Harstad trawl; MIK: Method lsaacs-Kidd midwater traw]

\begin{tabular}{|c|c|c|c|c|c|c|}
\hline Acoustical structure & Stn & Gear & Date (1993) & Time $(h)$ & Fishing depth (m) & Catches (kg per nautical mile) \\
\hline \multirow[t]{4}{*}{ Upper layer } & 292 & $\AA \mathrm{T}$ & 22 April & $04: 10$ & $145-100$ & $\begin{array}{l}\text { Maurolicus muelleri (2.1), Periphylla } \\
\text { periphylla }(0.7) \text {, Clupea harengus (0.6), } \\
\text { Pollachius virens }(0.5)\end{array}$ \\
\hline & 188 & $\mathrm{HT}$ & 18 April & $14: 50$ & $220-180$ & M. muelleri $(0.8)$, unidentified krill $(0.2)$ \\
\hline & 286 & $\mathrm{HT}$ & 19 April & $18: 00$ & $70-50$ & $\begin{array}{l}\text { M. muelleri }(0.8) \text {, Thysanoessa inermis }(0.7) \text {, } \\
\text { Meganyctiphanes norvegica }(0.07)\end{array}$ \\
\hline & 287 & $\AA T$ & 20 April & $13: 35$ & $230-200$ & M. muelleri $(6.7)$ \\
\hline \multirow[t]{2}{*}{$\begin{array}{l}\text { Intermediate } \\
\text { layer }\end{array}$} & 293 & HT & 22 April & $13: 00$ & $170-140$ & $\begin{array}{l}\text { T. inermis }(6.0), \text { M. muelleri }(0.4) \text {, } \\
\text { M. norvegica }(0.2) \text {, Nyctiphanes mega- } \\
\text { Jops }(0.06) \text {, Trisopterus esmarkii }(0.05) \text {, } \\
\text { Argentinus silus }(0.05)\end{array}$ \\
\hline & P1 & MIK & 23 April & $21: 30$ & $70-50$ & $\begin{array}{l}\text { T. inermis }(0.7) \\
\text { Thysanoessa longicaudata }(0.001)\end{array}$ \\
\hline $\begin{array}{l}\text { lntermediate/ } \\
\text { bottom associated } \\
\text { layer }\end{array}$ & 294 & $\mathrm{HT}$ & 22 April & $20: 25$ & $220-170$ & $\begin{array}{l}\text { T. inermis }(6.5), M \text {. norvegica }(2.9) \\
\text { T. esmarkii }(0.7), M \text { muelleri }(0.01) \text {, } \\
\text { A. silus }(0.01)\end{array}$ \\
\hline
\end{tabular}

the upper SSL (Table 1). Samples from the intermediate, diffuse layer consisted mainly of the krill Thysanoessa inermis (Table 1). The benthic boundary zone was not sampled.

During the cross-shelf transect, the vertical distribution of all targets changed abruptly after about $70 \mathrm{~km}$ of mapping. The upper layer (interpreted as mesopelagic fish; see 'Discussion') ascended by approximately $100 \mathrm{~m}$. There was a coinciding ascent of the diffuse targets (interpreted as krill). Demersal fish left the benthic boundary zone. This could be better visualized by expanding the bottom $10 \mathrm{~m}$ of the acoustic records (Fig. 2). These were not temporal effects, as similar patterns were observed by the 2 research vessels making their records almost $5 \mathrm{~h}$ apart.

Landward of this sudden rise, ascending 'demersal' fish were observed in the lower 50 to $100 \mathrm{~m}$ of the water column during the subsequent $\sim 50 \mathrm{~km}$ of acoustical recordings in daylight. Their distribution partly extended into the lower component of the krill layer, on several occasions apparently accompanied by a concurrent ascent of krill. The most prominent example of concurrent rise by fish and krill is presented in Fig. 3. Outside a patch of fish, the krill layer extended almost down to the sea floor. With increased numbers of fish rising from the benthic boundary zone, the distribution of krill became shallower, and a more compact SSL was formed about 100 in above bottom. Parallel to the ascent, the values of fish backscattering (a measure of fish biomass) increased by an order of magnitude (Fig. 3), and peaked in the region of shallowest krill distribution. Thereafter integrated fish values decreased and both fish and krill descended. The total backscattering of krill was fairly constant along this section (Fig. 3).

Trawl catches in the ascending layer consisted mainly of krill and Norway pout Trisopterus esmarkii (Table 1). Thysanoessa inermis was the only identifiable prey item in the stomachs of Norway pout (Table 2).

Table 2. Stomach content of a subsample of 9 Norway pout Trisopterus esmarkii from a midwater trawl catch at Stn 294 on 22 April 1993 (20:25 h European standard time: GMT $+1 \mathrm{~h}$ ). Bottom depth $295 \mathrm{~m}$, sampling depth 170 to $220 \mathrm{~m}$. Scale for stomach fullness is from 1 (empty) to 5 (full and distended). Scale for state of digestion is from 1 (fresh) to 5 (mushy)

\begin{tabular}{|c|c|c|c|c|}
\hline $\begin{array}{l}\text { Fish length } \\
\quad(\mathrm{cm})\end{array}$ & $\begin{array}{l}\text { Stomach } \\
\text { content }(g)\end{array}$ & $\begin{array}{l}\text { Dominant } \\
\text { prey item, } n\end{array}$ & $\begin{array}{l}\text { Stomach } \\
\text { fullness }\end{array}$ & $\begin{array}{l}\text { State of } \\
\text { digestion }\end{array}$ \\
\hline 11 & Empty & - & - & - \\
\hline 11 & 0.334 & $\begin{array}{l}\text { Thysanoessa inermis } \\
(17-20 \mathrm{~mm}), 5\end{array}$ & 4 & 1,3 \\
\hline 14 & 0.100 & T. inermis (19 mm). 5 & 3 & $2-3$ \\
\hline 14 & 0.085 & Unidentified krill, 2 & 3 & 3 \\
\hline 14 & Empty & - & 1 & - \\
\hline 15 & 0.466 & T. inermis $(20.21 \mathrm{~mm}), 2$ & 4 & - \\
\hline $1 j$ & 0.471 & 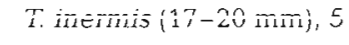 & 4 & 2 \\
\hline 16 & 0.169 & Unidentified krill, 2 & 3 & 3 \\
\hline 17 & 1.128 & Unidentified krill & 4 & 3 \\
\hline
\end{tabular}




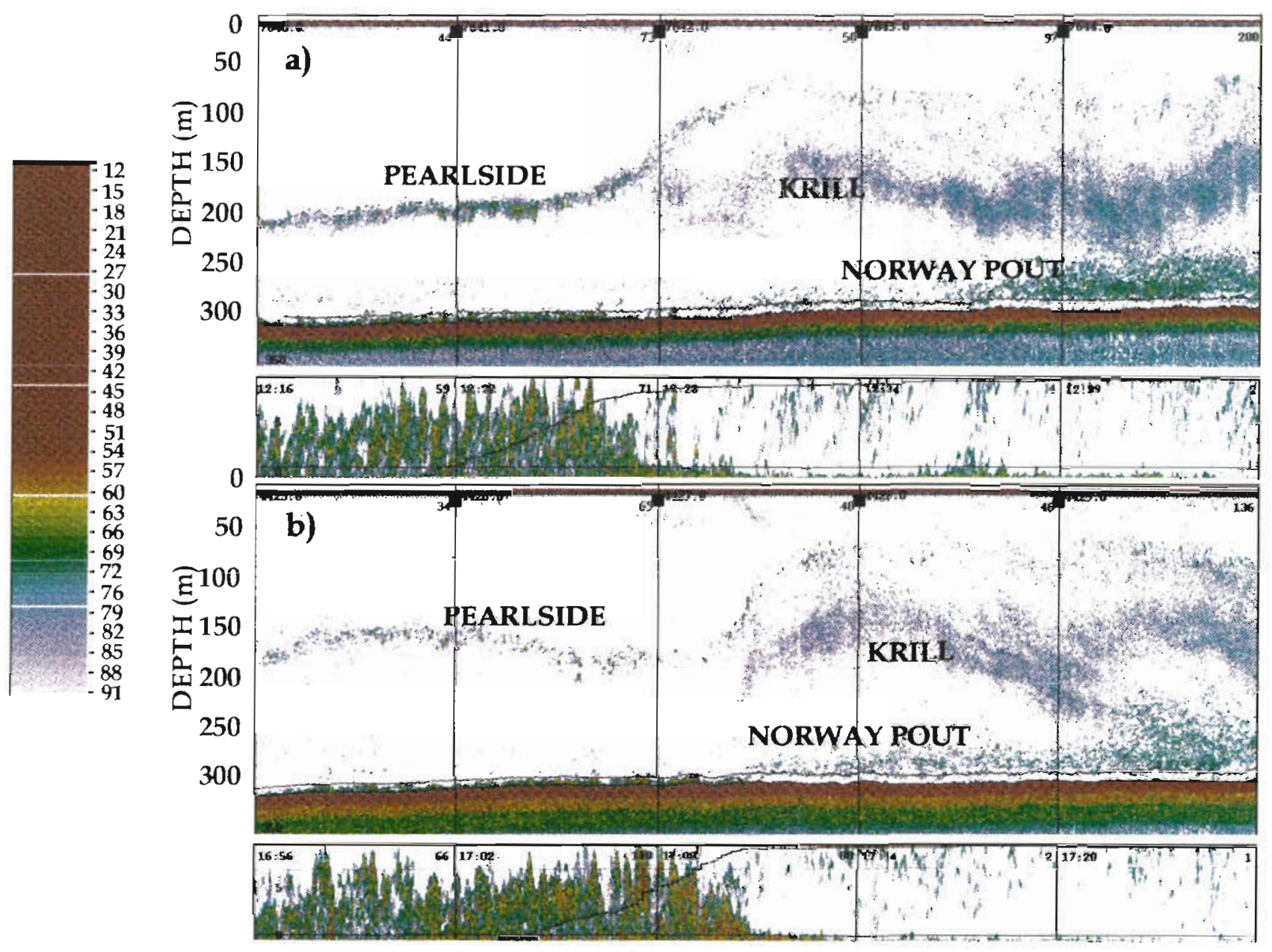

Fig. 2. Echograms (38 kHz) from (a) RV 'Johan Hjort' at 13:16-13:45 h European standard time (GMT + 1 h) and (b) RV 'G.O. Sars' at 17:56-18:25 h on 22 April 1993. Location of the abrupt changes in vertical distributions corresponds to Point A of Fig. 1. Color code refers to volume backscattering strength $(\mathrm{db})$. Vertical lines delineate nautical miles. Lower, narrow panels show vertical expansions of the lowermost $10 \mathrm{~m}$ above the sea floor. Build-up lines of integrated backscaltering for these bottom windows are superimposed. Identities of acoustical layers are suggested

\section{Environmental characteristics}

The abrupt changes in vertical distributions depicted in Fig. 2 were associated with a front, as demonstrated by concurrent drops in surface $(5 \mathrm{~m})$ salinity and temperature, and increased chl a (fluorescence) values (Fig. 4 ; point A). There was no apparent change in the hydrography at depth. Changes in surface salinity and temperature were relatively small, while fluorescence and light extinction inside the front were much higher than in oceanic water (Figs. 4 to 6; vertical profiles of light extinction not available from just outside the front).

The ascent of demersal fish and krill further landward, portrayed in Fig. 3, took place beneath a surface lens of slightly saltier, warmer water with intermediate concentrations of chl a (Fig. 4; between points B and C). There was no apparent change in the hydrography at depth (Fig. 6).

\section{DISCUSSION}

Identification of SSLs

The use of acoustics provides unsurpassed temporal and spatial coverage and also offers the advantage of mapping fish and larger zooplankton simultaneously. Identifications of targets may, however, represent a problem and must partly rely on supplementary methods. Based on the net catches, acoustic characteristics, and previous investigations, we feel confident that the 


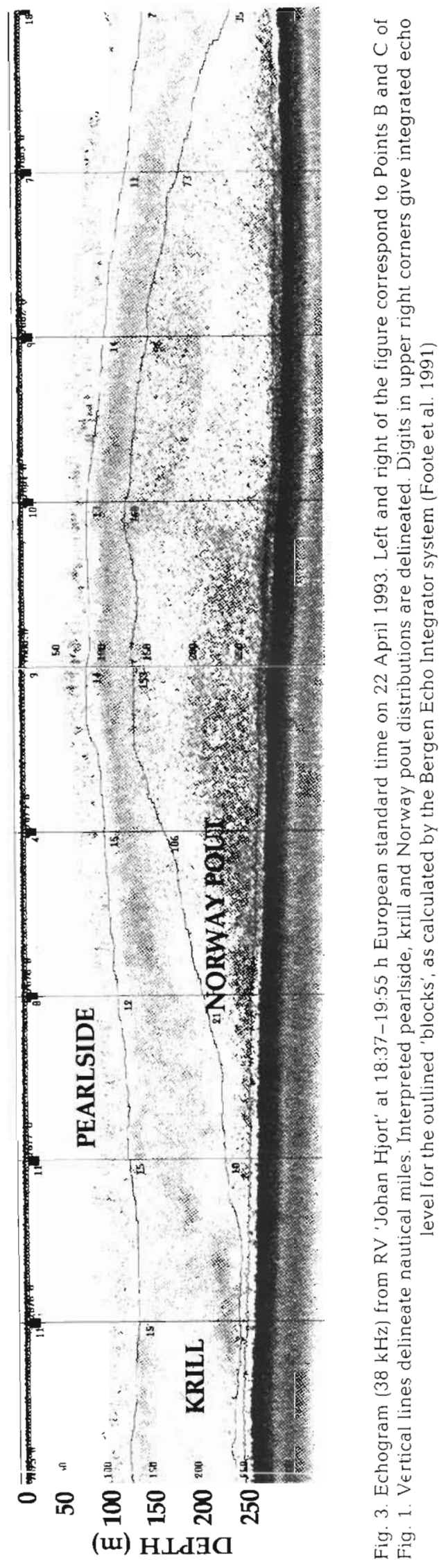

3 groups of targets addressed in this investigation are correctly identified.

Maurolicus muelleri prevailed in samples from trawling aimed at the upper mesopelagic SSL, though catches were small (Table 1). This corresponds to other of fshore sampling in this type of acoustical structure (Bergstad 1990, Melle et al. 1993). In Norwegian fjords, both video recordings and trawling have clearly revealed that $M$. muelleri is the main target in this kind of layer, characterized by narrow vertical extension and considerable horizontal patchiness (Giske et al. 1990, Skjoldal et al. 1993, Rasmussen \& Giske 1994, Bjelland 1995, authors' unpubl. results).
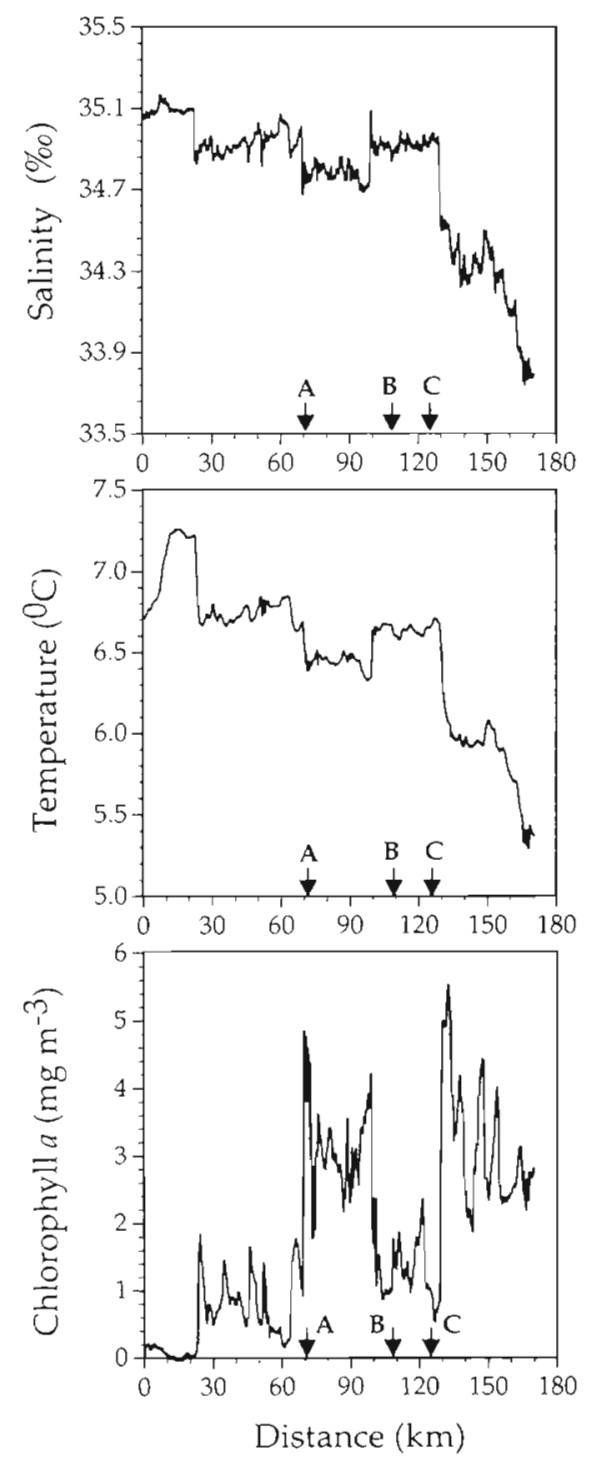

Fig. 4. Continuous measurements of salinity, temperature and chlorophyll a (as estimated by the regression Ch1 $a=11.5$ Fiuorescence $-5.3 ; \mathrm{r}^{2}=0.88, \mathrm{n}=9$ ) at $5 \mathrm{~m}$ depth during the crossshelf transect from oceanic (left) to coastal water (right). Points $A, B$, and $C$ denote locations referred to in Fig. 1 

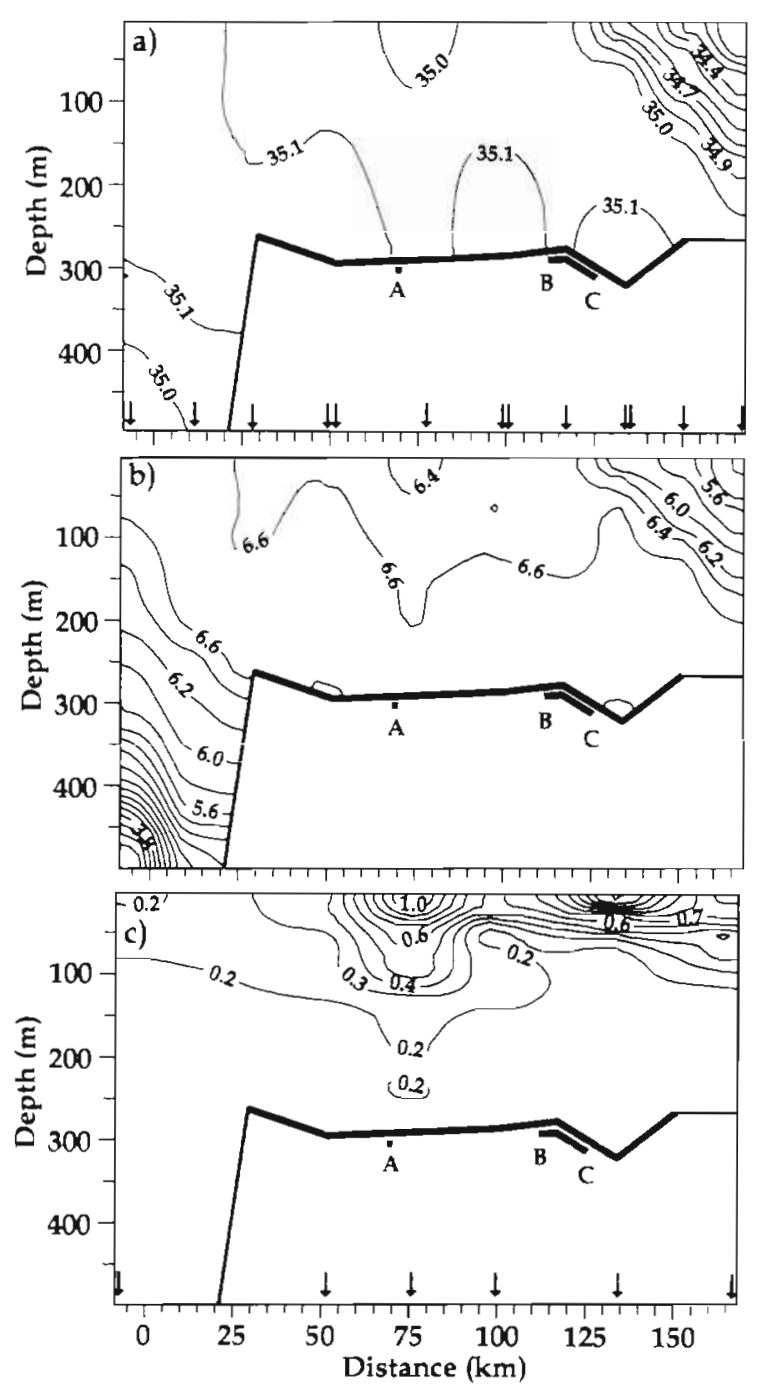

Fig. 5. Isolines of (a) salinity, (b) temperature and (c) fluorescence across the continental shelf from oceanic (left) to coastal water (right) on 22 April 1993. Bottom contour is processed from acoustical data obtained during the transect. CTD profiles from RV 'Johan Hort' and RV 'G.O. Sars' are combined while fluorescence results are from 'G.O. Sars'. Arrows depict sampling stations. Points $A, B$ and $C$ depict locations referred to in Fig. 1 The less haline and colder water shoreward of Point $C$ represents the Norwegian coastal current

Catches in the diffuse SSL were dominated by krill (predominantly Thysanoessa inermis and some Meganyctiphanes norvegica; Table 1). Also the acoustical signature and comparison between the 2 frequencies suggested that this SSL was composed of many relatively small organisms. While ascending into the upper $100 \mathrm{~m}$ at night, i.e. within the range of the $120 \mathrm{kHz}$ sounder, these targets were more distinctly revealed by the higher frequency (not shown). Krill is at the lower end of the detectable size range at $38 \mathrm{kHz}$, and
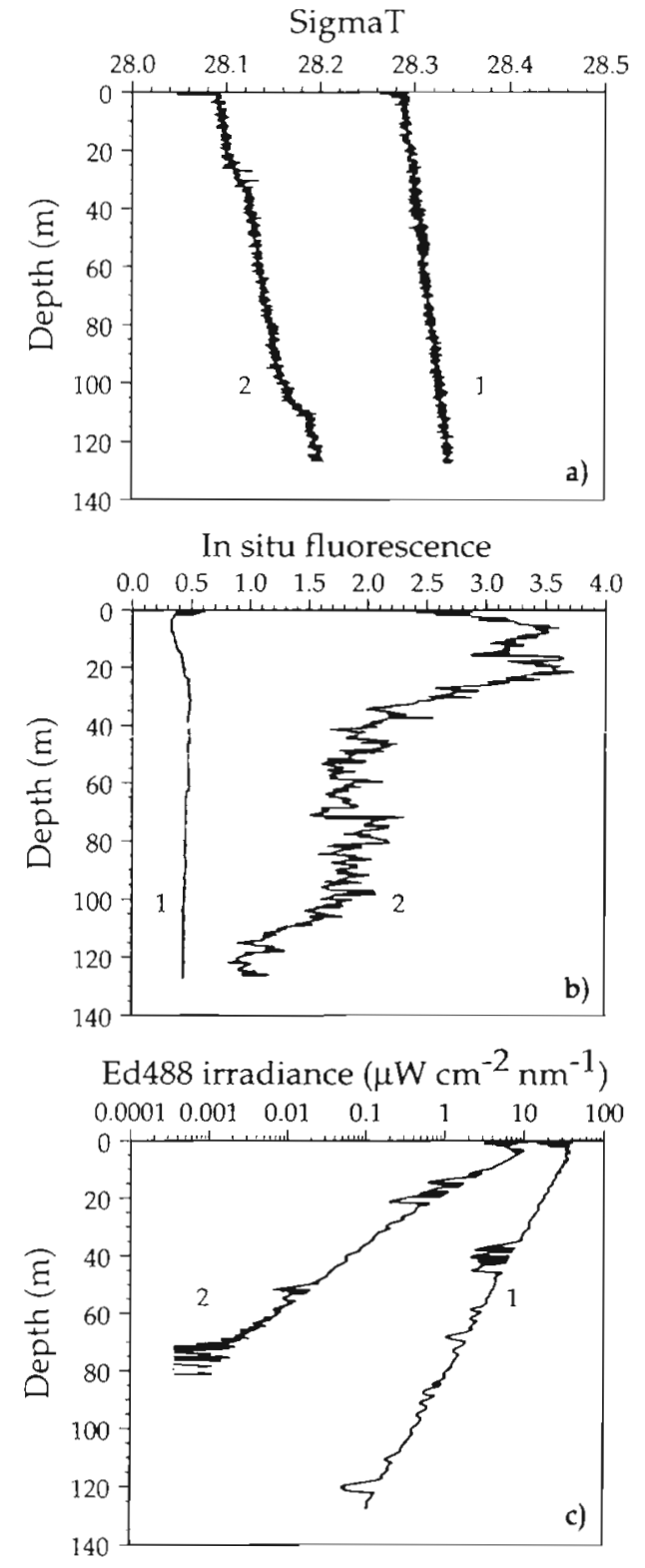

Fig. 6. Vertical profiles of (a) sigma T, (b) fluorescence, and (c) transmission of blue light in (1) waters outside the shelf break (Stn L1) and (2) just inside Point A (Stn L2)

will be better displayed at $120 \mathrm{kHz}$ (Everson et al. 1990, Foote et al. 1990, Greene et al. 1991).

We did not carry out bottom trawling during the survey, but have 1 trawl catch identifying the ascending fish as Norway pout. On other cruises, bottom trawling on the shelf has yielded catches dominated by Norway pout in similar acoustical structures (Torgersen 1995, unpubl. data from the Institute of Marine Research, Bergen). The color code of single fish echoes indicates that the prevailing demersal targets were relatively small fish. 


\section{Factors governing vertical distributions}

Distribution of scattering layers across fronts has elsewhere been found to follow water types (Sameoto 1982). Our results, however, were apparently not explainable by preference for a particular water mass, as temperature and salinity in deeper waters were fairly homogeneously distributed along the transect. We suggest that the 'shadow effect' caused by algal growth in waters inside the front played an instrumental part in shaping vertical distributions.

Light levels appeared to be roughly corresponding in the layer of Maurolicus muelleri outside and inside the front. Light intensity at the top of the pearlside layer just inside the front (taken as $80 \mathrm{~m}$ ) was 0.0002 and $0.0005 \mu \mathrm{W} \mathrm{cm} \mathrm{cm}^{-2} \mathrm{~nm}^{-1}$ for blue (488 $\mathrm{mm}$ ) and green $(520 \mathrm{~nm})$ light respectively. By extrapolating the light extinction curves for water outside the shelf break (Stn L1), corresponding values were found at $230 \mathrm{~m}$ (blue) and $170 \mathrm{~m}$ (green). The pearlside layer in this specific location was recorded between 180 and $210 \mathrm{~m}$. Previous studies have shown that the pearlside is very sensitive to fluctuating light, for example rapidly adjusting its vertical distribution in response to variable cloudiness (Giske et al. 1990, Balin̄o \& Aksnes 1993, Rasmussen \& Giske 1994j

Also, Norway pout and euphausiids are sensitive to the ambient light (e.g. Gordon 1977, Sameoto 1980, Kulka et al. 1982, Albert 1993) and may have responded to the 'dusk' inside the front. Besides, the algae represent a food source for the krill. In the example portrayed in Fig. 3, however, the vertical distribution of krill apparently shallowed in concordance with increased predation pressure from below. This was evidenced by enhanced fish abundance (an order of magnitude), their vertical extension into the krill layer and fish stomach content (Table 2). Alternatively to a causal relationship with krill adjusting their vertical distribution when exposed to the ascending predators, the upward displacement may have had a physical cause, such as internal waves (e.g. Haury et al. 1979). The incident took place fairly late in the afternoon ( $~ 0.5$ to $1.5 \mathrm{~h}$ prior to sunset), but the shallow distribution apparently did not reflect an initiation of diel vertical migration as the ascent was followed by a subsequent descent. The intermediate fluorescence of upper layers (Fig. 4) implies higher transparency than elsewhere on the inner shelf, but lower than in outer shelf waters.

\section{Trophic interactions}

Distribution of demersal Norway pout and krill was mainly vertically disjunct outside the front, while the pout ascended into the lower part of the krill layer inside the front, foraging on Thysanoessa inermis. Small fish, like Norway pout (e.g. Table 2), are themselves potential prey of visually hunting fish, and possibly become more vulnerable to predation when foraging in the water column (see for example Donnely \& Dill 1984, Lima \& Dill 1990). Piscivores need more light than planktivores to hunt efficiently since the numerical density of fish prey is much lower than zooplankton (Clark \& Levy 1988). Thus, the ratio of mortality risk to feeding rate for the planktivore reaches a minimum at intermediate levels of light intensity, a so-called 'antipredation window'. In the original model by Clark \& Levy (1988), 'antipredation windows' for planktivores occur for brief intervals at dawn and dusk. We suggest that the model may as well apply along horizontal transects in, or below, waters of different optical properties. This would be in accordance with laboratory studies ascribing increased planktivorous feeding in waters of intermediate turbidity to reduced potential risk to predators (Gregory \& Northcote 1993).

Acknowledgements. We thank Egil Sakshaug and Runar Dallokken for access to light data, and Karsten Hansen, Thomas Torgersen and Tom Viken for technical assistance. This is a contribution from the research program Mare Cognitum.

\section{LITERATURE CITED}

Aksnes DL, Giske J (1993) A theoretical model of aquatic visual feeding. Ecol Model 67:233-250

Albert OT (1993) Biology and ecology of Norway pout (Trisopterus esmarki Nilsson, 1855) in the Norwegian deep. ICES J Mar Sci 51:45-61

Balino BM, Aksnes DL (1993) Winter distribution and migration of the sound scattering layers, zooplankton and micronekton in Masfjorden, western Norway. Mar Ecol Prog Ser 102:35-50

Barange M. Pillar SC (1992) Cross-shelf circulation, zonation and maintenance mechanisms of Nyctiphanes capensis and Euphausia hanseni (Euphausiacea) in the northern Benguela upwelling system. Cont Shelf Res 12:1027-1042

Bergstad OA (1990) Ecology of the fishes of the Norwegian deep: distribution and species assemblages. Neth J Sea Res 25:237-266

Bjelland $O$ (1995) Life-history tactics of two fjordic populations of Maurolicus muelleri. Master's thesis, University of Bergen

Bollens SM, Frost BW (1989) Zooplanktivorous fish and variable diel vertical migration in the marine planktonic copepod Calanus pacificus. Limnol Oceanogr 34:1072-1083

Bollens SM, Frost BW (1991) Diel vertical migration in zooplankton: rapid individual response to predators. J Plankton Res 13:1359-1365

Bollens SM, Frost BW, Lin TS (1992a) Recruitment, growth, and diel vertical migration of Euphausia pacifica in a temperate fjord. Mar Biol 114:219-228

Bollens SM, rrost BW, l'horeson DS, Watts SJ (1992b) Diel vertical migration in zooplankton: fjeld evidence in support of the predator avoidance hypothesis. Hydrobiologia 234:33-39 
Clark CW, Levy DA (1988) Diel vertical migration by juvenile sockeye salmon and the antipredation window. Am Nat 131:271-290

Dawidowicz P, Loose CJ (1992) Metabolic costs during predator-induced diel vertical migration of Daphnia. Limnol Oceanogr 37:1589-1595

Donnely WA, Dill M (1984) Evidence for crypsis in coho salmon, Oncorhyncus kisutch (Walbaum), parr: substrate colour preference and achromatıc reflectance. J Fish Biol 25:183-195

Everson 1, Watkins JL, Bone DG, Foote KG (1990) Implications of a new acoustic target strength for abundance estimates of Antarctic krill. Nature 345:338-340

Fiksen $\varnothing$, Giske $J$ (1995) Vertical distribution and population dynamics of copepods by dynamic optimization. ICES $J$ Mar Sci 52:483-503

Foote KG, Everson I, Watkins JL, Bone DG (1990) Target strengths of Antarctic krill (Euphausia superba) at 38 and $120 \mathrm{kHz}$. J Acoust Soc Am 87:16-24

Foote KG, Knutsen HP, Korneliussen RJ, Nordbø PE, Røang K (1991) Postprocessing system for echo sounder data. J Acoust Soc Am 90:37-38

Frost BW, Bollens SM (1992) Variability of diel vertical migration in the marine planktonic copepod Pseudocalanus newmani in relation to its predators. Can J Fish Aquat Sci 49:1137-1141

Genin A, Greene C, Haury L, Wiebe PH, Gall G, Kaartvedt S, Meir E, Fey C, Dawson J (1994) Daily gap formation in oceanic zooplankton distributions over abrupt topography. Deep Sea Res 41:941-951

Genin A, Haury LR, Greenblatt P (1988) Interactions of migrating zooplankton with shallow topography: predation by rockfishes and intensification of patchiness. Deep Sea Res 35:151-175

Giske J, Aksnes DL, Baliño BM, Kaartvedt S, Lie U, Nordeide JT, Salvanes AGV, Wakili SM, Aadnesen A (1990) Vertical distribution and trophic interactions of zooplankton and fish in Masfjorden, Norway. Sarsia 75:65-81

Giske J, Aksnes DL, Fiksen $\oslash$ (1994) Visual predators, environmental variables and zooplankton mortaluty risk. Vie Milieu 44:1-9

Gliwicz ZM (1986) A lunar cycle in zooplankton. Ecology 67: $883-897$

Gordon JDM (1977) The fish populations in the inshore waters of the west of Scotland. The biology of the Norway pout (Trisopterus esmarkii). J Fish Biol 10:417-430

Greene CH, Stanton TK, Wiebe PH, McClatchie S (1991) Acoustic estimates of Antarctic krill. Nature 349:110

Gregory RS, Northcote TG (1993) Surface, planktonic and benthic foraging by juvenile chinook salmon (Oncorhynchus tshawytscha) in turbid laboratory conditions. Can J Fish Aquat Sci 50:233-240

Haury LR, Briscoe MG, Orr MH (1979) Tidally generated internal wave packets in Massachusetts Bay. Nature 278: $312-317$

Hobson ES (1989) Predation on ocean krill. Science 243:237

Hobson ES, Chess JR (1986) Diel movements of resident and transient zooplankters above lagoon reefs at Enewetak A.toll, Marshall Islands. Pacif Sci 40:7-26

Huang C, Uye S, Onbe T (1993) Ontogenetic diel vertical migration of the planktonic copepod Calanus sinicus in the Inland Sea of Japan. Mar Biol 117:289-299
Isaacs JD, Schwartzlose RA (1965) Migrant sound scatters: interaction with the sea floor. Science 150:1810-1813

Johnsen GH, Jakobsen PJ (1987) The effect of food limitation on vertical migration in Daphnia longispina. Limnol Oceanogr 32:873-880

Kaartvedt S (1993) Drifting and resident plankton. Bull Mar Sci 53:154-159

Kulka DW, Corey S, lles TD (1982) Community structure and biomass of euphausids in the Bay of Fundy. Can J Fish Aquat Sci 39:326-334

Lima S, Dill LM (1990) Behavioral decisions made under the risk of predation: a review and prospectus. Can J Zool 68:619-640

Melle W, Kaartvedt S, Knutsen T, Dalpadado P, Skjoldal HR (1993) Acoustic visualization of large scale macroplankton and micronekton distributions across the Norwegian shelf and slope of the Norwegian Sea. ICES Comm Meet 1993/L:44

Munk P (1988) Catching large herring larvae: gear applicabiity and larval distribution. J Cons Int Explor Mer 45:97-104

Nedreaas K, Smedstad OM (1987) Abundance and distribution of postlarvae in the 0-group saithe survey in the North Sea and the Northeast Arctic in 1986 and 1987. ICES 6:31

Neill WE (1992) Population variation in the ontogeny of predator-induced vertical migration of copepods. Nature $356: 54-57$

Rasmussen OI, Giske J (1994) Life-history parameters and vertical distnbution of Maurolicus muelleri in Masfjorden in summer. Mar Biol 120:649-664

Rosland R, Giske J (1994) A dynamic optimization model of the diel vertical distribution of a pelagic planktivorous fish. Prog Oceanogr 34:1-43

Sameoto DD (1980) Relationships between stomach contents and vertical migration in Meganyctiphanes norvegica, Thysanoëssa raschii and T. Lnermis (Crustacea Euphausiacea). J Plankton Res 2:129-143

Sameoto DD (1982) Zooplankton and micronekton abundance in acoustic scattering layers on the Nova Scotian slope. Can J Fish Aquat Sci 39:760-777

Skjoldal HR, Wiebe P, Knutsen R, Postel L (1993) Preliminary report from the sea-going workshop in Norway June 1993 on intercomparison and evaluation of methods for sannpling and determination of zooplankton distribution and biomass (ICES study group on zooplankton production). ICES Comm Meet 1993/L:45

Thetmeyer $H_{1}$ Kils U (1995) To see and not be seen: the visibility of predator and prey with respect to feeding behaviour. Mar Ecol Prog Ser 126:1-8

Torgersen T (1995) Akustiske studier av fisk og makroplankton over kontinentalsokkelen og det østlige Norskehavet, mars 1992; fordeling, atferd og metodiske problemer. Master's thesis, University of Oslo

Valdemarsen JW, Misund OA (1995) Trawl design and techniques used by Norwegian research vessels to sample the pelagic zone. In: Hylen A (ed) Precision and relevance of pre-recruit studies for fishery management related to fish stocks in the Barents Sea area and adjacent waters. The sixth Norwegian-Russian symposium, Bergen, 14-17 June 1994. Institute of Marine Research, Bergen, p 135-144

Zaret TM, Suffern JS (1976) Vertical migration in zooplankton as a predator avoidance mechanism. Limnol Oceanogr 21: $804-813$ 